\title{
Percutaneous Removal of a Broken Malecot Nephrostomy Tube
}

\section{Kırık Malecot Nefrostomi Tüpünün Perkütan Yolu ile Çıkarılması}

\author{
(D) Tariq Asi, (D) Hasan Serkan Doğan \\ Hacettepe University Hospital Faculty of Medicine, Department of Urology, Ankara, Turkiye
}

\begin{abstract}
We report a case of a broken re-entry Malecot nephrostomy tube inserted after an uneventful percutaneous nephrolithotomy (PCNL) procedure. The remained parts within the renal pelvis and around the kidney were removed using a percutaneous approach under general anesthesia using the PCNL access tract. Although this complication did not cause severe morbidity, it converted a successful uneventful PCNL procedure to a grade IIIB complicated one according to the modified Clavien classification system. This complication should be held in mind and a percutaneous approach should be considered before attempting an open surgery.
\end{abstract}

Keywords: Broken percutaneous nephrostomy tube, Re-entry Malecot, Clavien IIIB, Endoscopic intervention

Öz

Başarılı perkütan nefrolitotomi (PCNL) prosedüründen sonra kırık Malecot nefrostomi tüpü olan bir olgu sunuyoruz. Kalan kısım PCNL akses traktı kullanılarak genel anestezi altında perkütan yaklaşımla çıkarıldı. Bu komplikasyon ciddi morbiditeye neden olmamasına rağmen, sorunsuz bir PCNL prosedürünü modifiye Clavien sistemine göre IIIB komplike bir olguya dönüştürdü. Bu komplikasyon akılda tutulmalı ve açık cerrahi girişimden önce perkütan bir yaklaşım düşünülmelidir.

Anahtar Kelimeler: Kırık perkütan nefrostomi tüpü, Re-entry Malecot, Clavien IIIB, Endoskopik yaklaşım

\section{Introduction}

Epidemiological studies of nephrolithiasis have demonstrated increasing prevalence and incidence of the disease over the last several decades (1). Percutaneous nephrolithotomy (PCNL) is considered the first-line treatment for large kidney stones (2). It is considered a safe procedure with low rates of serious complications (3). In an attempt to provide an objective, unified classification of PCNL complications, the modified Clavien classification system for surgical complications has been adopted (4). Therefore, rare complications and their management should be reported.

We report a case of a broken re-entry Malecot nephrostomy tube after an uneventful PCNL procedure. The retained tube was removed under general anesthesia by percutaneous approach using PCNL access tract. This event upgraded an uncomplicated case to grade IIIB complicated one despite the uneventful successful operation.

\section{Case Presentation}

A 68 years old female obese patient, who presented with periodic left flank pain was diagnosed with left renal multiple stones measuring 5-14 mm. She underwent PCNL in the prone position under general anesthesia. Access to inferior calyceal system was performed and dilated until an $30 \mathrm{~F}$ Amplatz sheath was placed. The stones were fragmented and removed completely. After sheath removal, a $20 \mathrm{~F}$ re-entry nephrostomy catheter was inserted into the renal pelvis.

The postoperative period was uneventful. On the second day antegrad pyelography showed passage to the bladder without extravasation. The nephrostomy tube was clamped and removed after 6-8 hours as no fever or severe pain occurred. During removal, the tube came out broken and the retained part was not seen on physical examination. The retained part was far away from subcutaneous tissue on X-ray (Figure 1). The tube was broken at the level of the renal capsule as shown in

Correspondence: Tariq Asi MD, Hacettepe University Hospital Faculty of Medicine, Department of Urology, Ankara, Turkiye Phone: +90312305 1885 E-mail: tarikasi07@gmail.com ORCID-ID: orcid.org/0000-0001-7330-5890

Received: 30.12 .2018

Accepted: 5.03 .2019

Cite this article as: Asi T, Doğan HS. Percutaneous Removal of a Broken Malecot Nephrostomy Tube. J Urol Surg 2019;6(2):162-164.

${ }^{\circ}$ Copyright 2019 by the Association of Urological Surgery / Journal of Urological Surgery published by Galenos Publishing House. 
non-contrast computed tomography (CT). Fragments thought to be related to the tube were seen in the CT imaging on the perirenal fat. After taking informed consent, an endoscopic intervention through the PCNL access tract was performed one day later. Following the placement of ureteral catheter by cystoscopy, the prone position was given. The tract site was not completely obliterated and the patent previous percutaneous tract was gradually dilated and access to the collecting system was achieved. The retained half of the Malecot catheter was extracted out using grasping forceps (Figure 2). Then, by using the nephroscope within the Amplatz sheath, the perirenal area was explored and the broken small parts of the Malecot part were found and taken out by grasping forceps. After the completion of the percutaneous intervention, the patient was given cystoscopic position and a double J stent was placed to ease the closure of the access tract. After that the patient

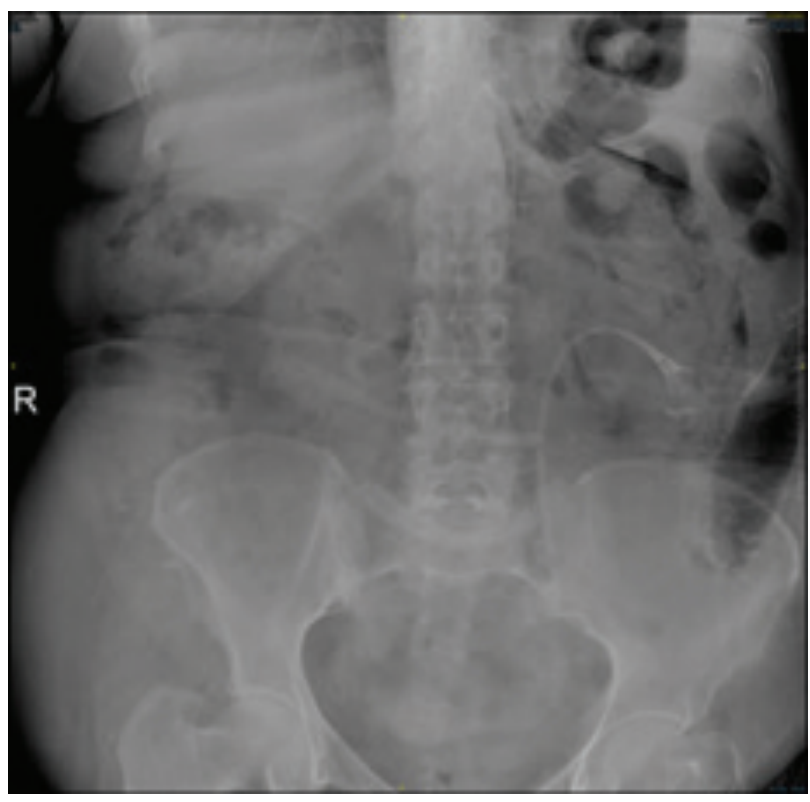

Figure 1. X-ray showing the broken re-entry Malecot nephrostomy tube

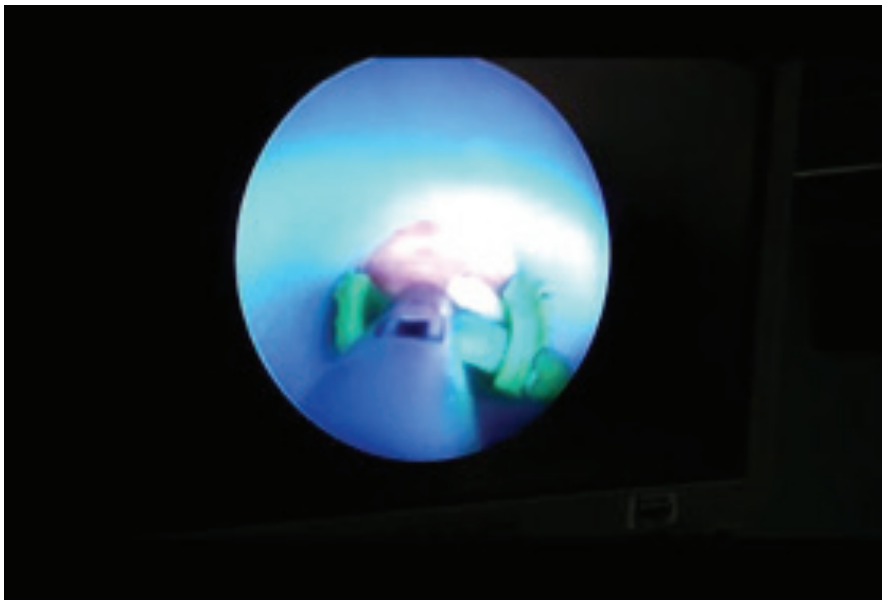

Figure 2. The retained half of the Malecot catheter was extracted out using grasping forceps recovered well and the JJ stent was removed 2 weeks by flexible cystoscope.

\section{Discussion}

Epidemiological studies of nephrolithiasis have demonstrated increasing prevalence and incidence of the disease over the last several decades (1). Minimally-invasive treatment modalities including extracorporeal shockwave lithotripsy, retrograde intrarenal surgery and PCNL are considered the choice in most cases. PCNL -with low complication rates- is considered the first and standard therapy for large kidney stones $(2,3)$.

Despite the use of PCNL procedure for many years, the literature is still weak in the aspect of a standard complication grading system (5). The complication types and rates show significant variables between observers. While some investigators consider a minor clinically insignificant complications as normal postoperative course, others would regard them as complications (4). This lack of a standard complication grading system result in a high variety of the reported complication rates, which range between 4 and 50.8\% (6). Using the modified Clavien classification, system Rosette et al. (3) reported a complication rate of $20.5 \%$ (grade I or II: $16.4 \%$, grade IIIA or IIIB: $3.6 \%$ and grade IV: $0.5 \%)$. The Clavien grade III includes any complication requiring surgical, endoscopic or radiological intervention (7). Our case could be classified as a grade IIIB complication because the retained broken re-entry Malecot nephrostomy tube was removed via endoscopic procedure under general anesthesia.

The tube was inserted properly and removed without any extreme power. The tube was tension-free in the post-operative period. The CT imaging showed the deep location of the retained part just at the renal parenchyma; besides that, there was another small fragment inside the perirenal fat tissue. These signs require an intervention under general anesthesia. Reviewing the literature, we could find only one similar case treated with open surgical intervention. As in our case, catheter malfunction was expected to be the reason (8). A web search done by Ozveren and Şahin (8) revealed two incidents of broken drainage tubes. Eisenberg et al. (9) reviewed their experience with endoscopic management of renal foreign bodies and reported that the foreign bodies included ureteral stents, nephrostomy tubes, the inner core of a guidewire, nephrostomy tube pull string and a laser fiber. However, they had no case of nephrostomy tube broken as ours.

As many studies report no difference in outcomes and complication rates in obese patients, we assume that obesity was not the reason in our case (10).

Although classic PCNL is still the standard method used, there are many reports showing better outcomes related to blood 
transfusion and length of hospital stay using small-bore PCNL, tubeless PCNL or totally tubeless PCNL (11). Hence, broken retained tube is not the only complication that can be seen related to the drainage method used. Tamura et al. (12) reported 3 cases of entrapped Malecot catheters managed with interventional techniques. A randomized trial comparing tubeless PCNL and tailed stent PCNL reported JJ stent dislodgement in 25\% of patients (13). In order to decrease the risk of damage, the stylet inside the re-entry nephrostomy catheter should be used during the removal by straightening the Malecot part to avoid forceful manipulations.

\section{Conclusion}

As a result, an unexpected device-related complication like a retained broken Malecot nephrostomy tube may significantly affect the outcome of PCNL. In case of such an unexpected complication, radiological evaluation should be done and percutaneous approach -if possible- should be considered before the closure of the tract and attempting an open surgery. By this management, we have been successful in treating a complication of a minimally-invasive surgery by a minimallyinvasive method which is compatible with the sense of surgery.

\section{Ethics}

Informed Consent: It was taken.

Peer-review: Externally peer-reviewed.

\section{Authorship Contributions}

Concept: T.A., H.S.D., Design: T.A., H.S.D., Data Collection and/ or Processing: T.A., H.S.D., Analysis and/or Interpretation: T.A., H.S.D., Literature Research: T.A., H.S.D., Writing: T.A., H.S.D.

Conflict of Interest: No conflict of interest was declared by the authors.

Financial Disclosure: None.

\section{References}

1. Ziemba JB, Matlaga BR. Epidemiology and economics of nephrolithiasis. Investig Clin Urol 2017;58:299-306.
2. Türk C, Petřik A, Sarica K, Seitz C, Skolarikos A, Straub M, Knoll T. EAU guidelines on interventional treatment for urolithiasis. Eur Urol 2016;69:475-482.

3. Rosette Jdl, Assimos D, Desai M, Gutierrez J, Lingeman J, Scarpa R, Tefekli A; CROES PCNL Study Group. The clinical research office of the endourological society percutaneous nephrolithotomy global study: indications, complications, and outcomes in 5803 patients. J Endourol 2011;25:11-17.

4. Tefekli A, Karadag MA, Tepeler K, Sari E, Berberoglu Y, Baykal M, Sarilar 0 , Muslumanoglu AY. Classification of percutaneous nephrolithotomy complications using the modified clavien grading system: looking for a standard. Eur Urol 2008;53:184-190.

5. Opondo D, Gravas $S$, Joyce $A$, Pearle $M$, Matsuda $T$, Sun $Y-H$, Assimos $D$, Denstedt J, de la Rosette J. Standardization of patient outcomes reporting in percutaneous nephrolithotomy. J Endourol 2014;28:767-774.

6. Kyriazis I, Panagopoulos V, Kallidonis P, Özsoy M, Vasilas M, Liatsikos E. Complications in percutaneous nephrolithotomy. World J Urol 2015;33:1069-1077.

7. Mandal S, Goel A, Kathpalia R, Sankhwar S, Singh V, Sinha RJ, Singh BP, Dalela D. Prospective evaluation of complications using the modified Clavien grading system, and of success rates of percutaneous nephrolithotomy using Guy's Stone Score: A single-center experience. Indian J Urol 2012;28:392398.

8. Ozveren B, Sahin A. An unusual cause of Grade IIlb Clavien complication of percutaneous nephrolithotomy: Broken and retained Malecot nephrostomy catheter. Can Urol Assoc J 2016;10:122-124.

9. Eisenberg ML, Lee KL, Stoller ML. Endoscopic management of retained renal foreign bodies. Urology 2009;73:1189-1194.

10. Alyami FA, Skinner TA, Norman RW. Impact of body mass index on clinical outcomes associated with percutaneous nephrolithotomy. Can Urol Assoc J 2013;7:197-201.

11. Lee JY, Jeh SU, Kim MD, Kang DH, Kwon JK, Ham WS, Choi YD, Cho KS Intraoperative and postoperative feasibility and safety of total tubeless, tubeless, small-bore tube, and standard percutaneous nephrolithotomy: a systematic review and network meta-analysis of 16 randomized controlled trials. BMC Urol 2017;17:48.

12. Tamura A, Arai $Y$, Sone $M$, Sugawara $S$, Ishii $H$, Morita $S$, Haraguchi TJIR. Management of Entrapped Malecot Catheters. Interventional Radiology 2018;3:93-95.

13. Choi M, Brusky J, Weaver J, Amantia M, Bellman GC. Randomized trial comparing modified tubeless percutaneous nephrolithotomy with tailed stent with percutaneous nephrostomy with small-bore tube. J Endourol 2006;20:766-770. 